is an officer of the Department of Justice, though not in name an Assistant Attorney General.

Mr. Woolsey is, as the members of the Society and as the readers of this Journal know, a member and a contributor to the Journal. He has contributed to its columns two admirable papers, one in 1909 on "Early Cases on the Doctrine of Continuous Voyage" - a doctrine with which he was thus fortunately familiar during the European War - and another in 1910 entitled "A Comparative Study of the South African Constitution." Recently he delivered a notable address on "Economic Considerations of International Organization" before the Eleventh Annual Meeting of the Society, which, when it appears in the volume of the proceedings of the Society for 1917, will be regarded as possessing permanent value.

The opportunities of service were never greater than at the present time. The complicated questions of neutrality have given way to the complicated questions of war, and it is a matter of congratulation that the law officer of the Department of State is by natural ability, training, and experience as well fitted to cope with the one as with the other.

James Brown ScotT.

\title{
THE ANNUAL MEETING OF THE SOCIETY
}

The Eleventh Annual Meeting of the Society was held in Washington, April 26 to 28 last. The meeting was opened on the evening of the 26th, in the New Willard Hotel, by the Honorable Elihu Root, President of the Society, who, although when he selected the subject of his presidential address several weeks prior to the meeting, he had no idea that he would soon be called upon to head the American mission to the new-born democracy of Russia, delivered a stirring address upon "The Effect of Democracy on International Law." It was a peculiar privilege of the members of the Society that to them Mr. Root made his last public utterance before leaving the United States to stir the Russian peoples and armies to renewed action in defense of democracy and the supremacy of law among nations. The theme of his address, the thought that he left with his fellow-members in the Society, the message that he took with him to the masses of new Russia struggling for liberty against autocracy both within and without their country, was contained in the following concluding passages: 
The world cannot be half democratic and half autocratic. It must be all democratic or all Prussian. There can be no compromise. If it is all Prussian, there can be no real international law. If it is all democratic, international law, honored and observed, may well be expected as a natural development of the principles which make democratic self-government possible.

The democracies of the world are gathered about the last stronghold of autocracy, and engaged in the conflict thrust upon them by dynastic policy pursuing the ambition of rulers under claim of divine right for their own aggrandizement, their own glory, without regard to law or justice, or faith. The issue today and tomorrow may seem uncertain, but the end is not uncertain. No one knows how soon the end will come, or what dreadful suffering and sacrifice may stand between; but the progress of the great world movement that has doomed autocracy cannot be turned back, or defeated.

That is the great peace movement.

There the millions who have learned under freedom to hope and aspire for better things are paying the price that the peaceful peoples of the earth may live in security under the protection of law based upon all embracing justice and supreme in the community of nations.

The presidential address was followed by two papers on "The Status of Armed Merchantmen," the first by the Honorable Chandler P. Anderson, formerly Counselor to the Department of State, and the second by Mr. Ellery C. Stowell, Associate Professor of International Law in Columbia University in the City of New York. The subject was informally discussed by Mr. Maurice Leon, of the New York Bar. A pleasing feature of the opening session was the receipt of cabled greetings and best wishes from Mr. Antonio S. de Bustamante, President of the Cuban Society of International Law. An appropriate acknowledgment was sent by the Society on the following day.

On Friday morning, April 27th, the Society considered the question of "Attacks upon Enemy Merchant Vessels." The subject was opened with a paper by Mr. Charles Cheney Hyde, of the Chicago Bar, Professor of International Law in Northwestern University. It was informally discussed by Mr. Everett P. Wheeler, of the New York Bar. This was followed by a consideration of "Some Economic Aspects of International Organization." Mr. Lester H. Woolsey, the newly appointed Solicitor for the Department of State, led this subject with a prepared paper, and was followed by informal remarks from Professor Philip Marshall Brown, of Princeton University, Rear Admiral Colby M. Chester of the U. S. Navy, Mr. Charles Noble Gregory, of the Bar of the District of Columbia, Mr. Denys P. Myers, of the World Peace Foundation, Boston, Mass., Professor George G. Wilson, Pro- 
fessor of International Law in Harvard University, Mr. Walter S. Penfield, of the Bar of the District of Columbia, Mr. James Brown Scott, Special Adviser to the Department of State, Mr. Bernard C. Steiner, of Baltimore, Md., and Mr. Charles S. Brand, of the New York Bar. At this session, the Society unaminously adopted the following resolution, upon motion of $\mathrm{Mr}$. Sterling $\mathrm{E}$. Edmunds, of the St. Louis Bar:

Whereas, the legal training of those of our citizens in military and international law is peculiarly necessary in this war, which is essentially one for the vindication of law; and,

Whereas, the usual educational facilities of the Government of the United States may not be adequate to so large an added task; therefore, be it

Resolved, that the American Society of International Law offers to the Government of the United States the services of its members as instractors in such branches of law in any manner in which their services may be desired.

In the afternoon of the same day, the question of international organization was further discussed. Mr. Raleigh C. Minor, Professor of International Law in the University of Virginia, delivered an address on the legislative aspects of the subject, and Mr. Charles G. Fenwick, Associate Professor of Political Science in Bryn Mawr College, read a paper on judicial international organization. In the informal discussions of these subjects which followed, the following members took part: Senator Henri LaFontaine, of Belgium, Mr. Theodore P. Ion, of Washington, D. C., Mr. Denys P. Myers, of Boston, Mass., Dr. David Jayne Hill, of Washington, D. C., Mr. Arthur G. Hays, of New York City, Mr. Justice Russell, of the Supreme Court of Nova Scotia, Rear Admiral Colby M. Chester, U. S. Navy, Mr. Edward C. Eliot, of St. Louis, Mo., and Mr. James Brown Scott, of Washington, D. C.

The consideration of the question of International Organization was continued at the evening session of the same day. The executive and administrative features of such organization were discussed in papers presented by Mr. William C. Dennis, of the Bar of the District of Columbia, and Mr. James Brown Scott, Director of the Division of International Law of the Carnegie Endowment for International Peace. After an address by Dr. Alejandro Alvarez, of Chile, Secretary General of the American Institute of International Law, upon "America and the Future Society of Nations," the previous question of executive and administrative international organization was discussed from the floor by Mr. Chester DeWitt Pugsley, of New York, Mr. Theodore P. Ion, 
Mr. Soterios Nicholson, of Washington, D. C., Mr. Arthur G. Hays, Senator Henri LaFontaine, and Professor Stanley K. Hornbeck, of the University of Wisconsin.

The session on Saturday morning, April 28th, was opened with an address by Senator Henri LaFontaine, of Belgium, upon the subject of "The Neutralization of States in the Scheme of International Organization." This was followed by a paper on the same subject by Mr. Cyrus F. Wicker, of the New York Bar, formerly of the American diplomatic service. The subject was then thrown open for discussion from the floor, and the following members took part: Dr. David Jayne Hill, Mr. Theodore P. Ion, Senator LaFontaine, Mr. Denys P. Myers, Mr. Nelson Gammans, of the New York Bar, Rear Admiral Colby M. Chester, and Mr. Theodore N. Van Derlyn, of Switzerland.

At the business meeting which followed the discussion Saturday morning, the Society reëlected the president, vice-presidents, and retiring members of the Executive Council. To fill the vacancy in the vice-presidents caused by the death of the Hon. Richard Olney, Hon. Simeon E. Baldwin was elected. The Honorable James L. Slayden was elected to fill a vacancy in the Executive Council. The Committee on the Study and Teaching of International Law and Related Subjects made a final report and was, upon request, discharged. The Committee on the Codification of International Law had been continued by vote of the Society on Friday evening. A resolution expressing its great sense of loss in the death of the Honorable Richard Olney, a member and Vice-President of the Society since its foundation, was unanimously adopted.

The Executive Council met immediately upon the adjournment of the Society, and reëlected the Chairman of the Council, the members of the Executive Committee, the Treasurer, the Recording and Corresponding Secretaries, and the Assistant to the Secretaries. The Board of Editors of the American Journal of International Law was likewise continued without change. The Council also continued the membership of the Standing Committee on Selection of Honorary Members, which made no recommendation for the present year, and the Standing Committee on Increase of Membership, except the chairman of the latter, - Mr. Scott having requested that he be allowed to withdraw, and Mr. Oscar S. Straus was appointed in his place. The Committee on the Annual Meeting was likewise continued, with one change, namely, Mr. George G. Wilson withdrew and Mr. Breckinridge Long, 
Assistant Secretary of State, was elected. The Committee on Publication of Proceedings was discontinued and these duties assigned to the Editor-in-Chief and Secretary of the Board of Editors of the JourNaL.

The meeting closed with the annual banquet at the New Willard Hotel on the evening of the 28th. Eighty-five members and guests were present. In the absence of President Root, who had left the city to prepare for his important public errand to Russia, the Honorable David Jayne Hill presided as toastmaster. In his remarks opening the speaking of the evening, Dr. Hill took occasion to reply to those who assert that international law has been destroyed. In answer to this statement he remarked:

International law can never be destroyed; it may be violated; its rules may be disobeyed, but so may the rules laid down by municipal lawg or by any legal system; but the law is there, and, so far as it goes, so far as it is the expression of that justice toward which all law aspires, it is a reality, in spite of violations. There is an analogy which has often impressed me, between the jurist and the man of science, who is exploring the arcana of nature with the idea of discovering the truth. There is not a scientific text-book in the world ten years old that is fit to teach in school or college today; and so, when we find that our international law books are already uncertain and will have to be revised, this should not in the least shake our faith in the reality and the solidity of the law. The search for justice is, to the jurist, what the search for truth is to the physicist, the psyhcologist, and the historian. Let me say, with the strongest possible emphasis, gentlemen, that so long as the idea and the ideal of justice persists in the human mind - and it will never cease to persist - there will be international law.

The speakers were Mr. Justice Russell, of the Supreme Court of Nova Scotia, Hon. Oscar S. Straus, M. Frederic Allain, in charge of the legal department of the French Purchasing Commission in the United States, Hon. Sheldon Amos, Judge of the Egyptian Mixed Court, and Professor B. E. Shatsky, of the University of Petrograd.

The complete addresses delivered during the meeting and at the banquet, together with the discussions, will appear in the Proceedings now in press and shortly to be issued.

George A. Finch.

\section{JUDGE ADVOCATES IN THE ARMY}

On June 15, 1917, the War Department announced the selection from civil life of twenty Judge Advocates, to serve with the first levy of approximately 600,000 men of the national draft army. It was stated that each of the Judge Advocates would be assigned to a division 